\title{
Labels on the maps of the Third Military Survey of Austria-Hungary and on the survey maps of the Military Geographical Institute (Wojskowy Instytut Geograficzny) in Warsaw in the light of survey manuals*
}

\begin{abstract}
Materials from topographic surveys had a serious impact on the labels on the maps that were based on these surveys. Collecting toponyms and information that were to be placed as labels on a final map, was an additional duty the survey officers were tasked with. Regulations concerning labels were included in survey manuals issued by the Austro-Hungarian Militärgeographisches Institut in Vienna and the Polish Wojskowy Instytut Geograficzny in Warsaw.

The analyzed Austro-Hungarian regulations date from the years 1875, 1887, 1894, 1903 (2nd ed.). The oldest manual was issued during the Third Military Survey of Austria-Hungary $(1: 25,000)$ and regulated the way it was conducted (it is to be supposed that the issued manual was mainly a collection of regulations issued prior to the survey launch). The Third Survey was the basis for the 1:75,000 Spezialkarte map. The other manuals regulated the field revisions of the survey. The analyzed Polish manuals date from the years 1925, 1936, and 1937.

The properties of the labels resulted from the military purpose of the maps. The geographical names' function was to facilitate land navigation whereas other labels were meant to provide a military map user with information that could not be otherwise transmitted with standard map symbols. A concern for not overloading the maps with labels is to be observed in the manuals: a survey officer was supposed to conduct a preliminary generalization of geographical names.

During a survey both an Austro-Hungarian and a Polish survey officer marked labels on a separate "label sheet". The most important difference between the procedures in the two institutes was that in the last stage of work an Austro-Hungarian officer transferred the labels (that were to be placed on a printed map) from the "label sheet" to the hand-drawn survey map, which made a cartographer not responsible for placing them in the right places. In the case of the Polish institute the labels remained only on the "label sheets".
\end{abstract}

Keywords: labels on maps, topographic survey, survey manual, Militärgeographisches Institut, Wojskowy Instytut Geograficzny

\section{Introduction}

In the times of the plane table the materials delivered by a surveyor from the field work had a fundamental influence on the shape and value of the map based on them. This essential dependence of a cartographer's work on the way a surveyor performed his duties was not limited only to the topographic content of a map, but covered the geographical names and other la-

\footnotetext{
* The access to some of the documents and the survey of the library holdings in Vienna were possible with financial support from an internal grant of the Institute of Slavic Studies of the Polish Academy of Sciences.
}

bels that enriched a map with additional pieces of information as well.

Collecting toponyms and other kinds of information that were to be placed as labels on a final map was an additional duty the survey officers were tasked with. They were obliged to properly spell and locate names and to mark their range. Mistakes made at this very stage could not be corrected later on by a cartographer. Thus, the fact that a cartographer was not to be blamed for shortcomings of a map's toponymic content was substantiated as follows:

“(...) a cartographer's responsibility for the form of a name is an indirect one. He receives 
names straight from a linguist, geographer or surveyor [WW: here in the quoted text a footnote is added: "Or, as it is the case with Wojskowy Instytut Geograficzny - from a survey apply to the maps that were later on based on the survey materials (though in the case of published maps the regulations concerning labels were convergent or at least very similar to

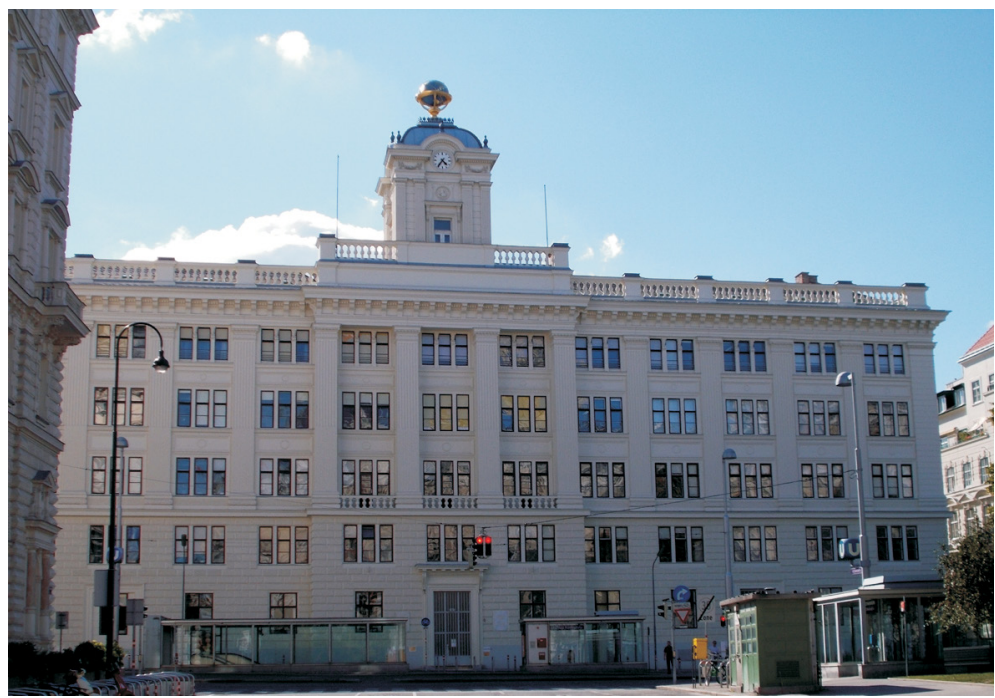

Fig. 1. The building of K. u. k. Militärgeographisches Institut in Vienna - a present look (photo by the author)

officer from the field"] and it is they that are in the first line responsible for the correctness of names. A cartographer's duty is to choose the best source, the scope of his specialization does not allow him to inspect the essence of the problem" (T. Czarnota 1930, pp. 104-105).

The way of collecting, spelling (i.e. using specific orthography) and placing toponyms on a survey sheet as well as the way of marking their range were regulated by appropriate survey manuals issued by the Austro-Hungarian Militärgeographisches Institut (MGI) in Vienna and the Polish Wojskowy Instytut Geograficzny (WIG) in Warsaw. A comparison of the regulations of these two institutes is justified insofar that in both cases the main method was the plane table survey and WIG was to a great extent an heir of MGI.

The author's aim is to analyze and assess the "technical" aspects of the names/labels in the materials of the Third Military Survey of Austria-Hungary and in the materials of the Polish Military Geographical Institute. The analysis is based on a set of survey manuals issued by the two institutes and generally does not the ones concerning survey sheets). The analysis of the formal (i.e. linguistic) properties of collected toponyms is the goal of another paper (W. Włoskowicz, Toponomastyczna praca topografa...) and these issues are to be mentioned here only in a very concise way.

\section{The analyzed survey manuals}

In the case of the Militärgeographisches Institut the analysis covers the following manuals: "Instruction für die militärische Landesaufnahme (Militärmappirung). II. Theil" from the year 1875 (hereafter referred to as IN1875) (fig. 2), "Instruction für die militärische Landesaufnahme (Militär-Mappirung und Reambulierung). II. Technischer Theil" from 1887 (IN1887) (later modified in the year 1894 - AN1894) and "Instruction für die militärische Landesaufnahme. II Technischer Theil" (2nd ed.) dating from 1903 (IN1903)'.

\footnotetext{
${ }^{1}$ I wish to express my thankfulness to Mr Prof. Peter Jordan and Mr Dipl.-Ing. Helmut Meckel from Vienna for making relevant parts of IN1903 available to me.
} 
The Third Military Survey of Austria-Hungary (so-called Franzisco-Josephinische Landesaufnahme) was conducted at the scale of $1: 25,000$ in the years $1869-1887$. It was meant to serve as the basis for the well-known Spezialkarte at the scale of 1:75,000, which was prepared and published sheet by sheet in the years 1873-1889 (F.P. Faluszczak 2011, p. 79). The launch of the survey had taken place prior to the issue of the oldest of the analyzed manuals that was the main document regulating the way the survey was conducted (A. Konias 2000 , p. 92). It is, though, to be supposed that the manual issued in a form of a book was mainly a collection of regulations issued prior to the survey launch. The publication of the next manual (IN1887) coincided with the end of the survey works. Nevertheless, the manual of 1887 was taken into account because - as it was the case with AN1894 and IN1903 as well - it may have been used during the field revision (update) of the survey maps of the 3rd survey and later on during the 4th survey (socalled Präzisionsaufnahme ${ }^{2}$ ). After the fall of Austria-Hungary the materials ${ }^{3}$ of the Third Survey were handed over to the successor states and therefore the Polish Military Geographical Institute possessed the sheets of the survey of Galicia, which used to be utilized by the Polish surveyors during field works, and especially served as the basis for the map revision done at a large scale (IN1925, p. 152).

The analyzed manuals of the Wojskowy Instytut Geograficzny are: "Instrukcja topograficzna. Część II techniczna" from the year 1925 (IN1925), "Instrukcja topograficzna Wojskowego Instytutu Geograficznego. Część III. Zdjęcie stolikowe" dating from 1936 (IN1936), and "Instrukcja topograficzna Wojskowego

\footnotetext{
2 The Fourth Survey had covered only some parts of Austria-Hungary and was continued after the WWI inside the new borders of Austria.

${ }^{3}$ Materials of the three Austrian surveys (Josephinische Landesaufnahme, Franziszeische Landesaufnahme, Franzisco-Josephinische Landesaufnahme) are availabele online at http://mapire.eu. However, at the time of the preparation of the present paper (Oct. 2014) the materials of the 3rd survey at the original scale 1:25,000 are available only for the Kingdom of Hungary (the presented maps are in most cases scans of copies of hand-drawn maps, not of the original hand-drawn maps); for the rest of the Austro-Hungarian territories the 3rd survey-based 1:75,000 Spezialkarte is presented (instead of the original 1:25,000 survey maps, and contrary to the given label).
}

Instytutu Geograficznego. Część IV. Unacześnianie map" from 1937 (IN1937). The Polish manuals are available through the Federacja Bibliotek Cyfrowych (Federation of Digital Libraries, fbc.pionier.net.pl).

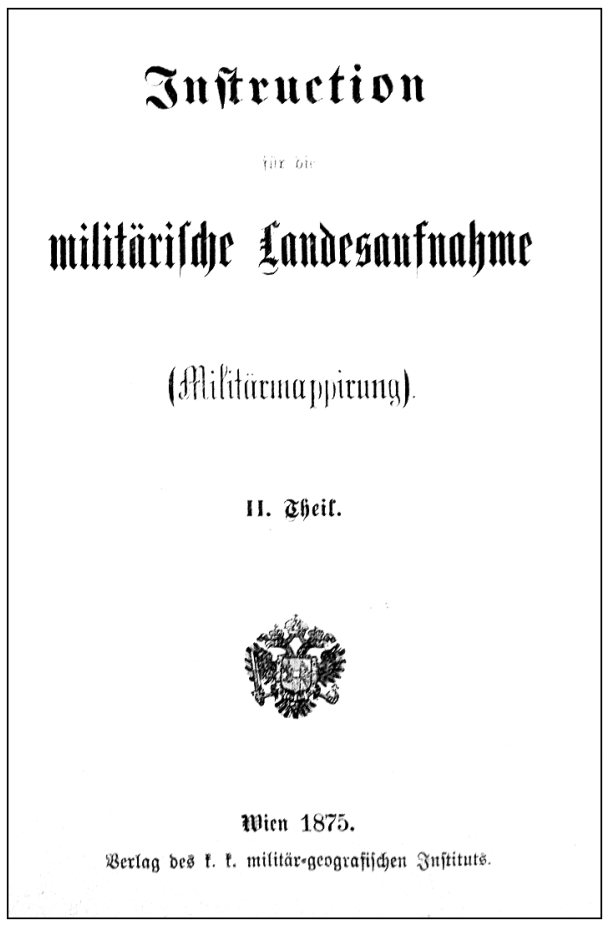

Fig. 2. The title page of the 1875 instruction

\section{Labels and the military purpose of the map}

The toponymic content of survey sheets and other labels were to a significant extent moulded by the military purpose of a map that was meant to be based on the survey. Both MGI and WIG were special units of the armed forces and the surveyors were army officers ${ }^{4}$ with general military education and experience. In the times of the 3rd survey of Austria-Hungary the surveyors still belonged to their units regiments of different combat arms (though, it

\footnotetext{
${ }^{4}$ In the case of MGI they were officers ranking from captain downwards. It was also possible for higher non-commissioned officers - deputy officers (Offiziersstellvertreter) - to become surveyors.
} 
is to be supposed that it was most probable for officers of the technical combat arms - mainly artillery and army engineers - to become a surveyor). They perceived the mapped area from the point of view of its potential tactical use, which was in conformity with the survey manuals (especially with the Austro-Hungarian ones) and had an impact on the generalization of toponyms and other labels.

The function the geographical names on a map were meant to fulfil was to ease finding one's position (which was the case with geographical names) and to provide a military map user with information that could not be otherwise transmitted with standard map symbols. Both Austro-Hungarian and interwar-Polish military survey services and military cartography paid much attention to the communicative value of names that a map user would "bring along" on a map and would use in communication with local people. Therefore, toponyms fixed on a map should be convergent with or (in the case of multi-language areas) at least very similar (in a way that guaranteed no misunderstandings) to the names used by the locals. The manual from the year 1903 stated that "only the names commonly familiar to the people are of value for a soldier"5 (IN1903, p. 167). The manual of 1887 ordered that in mountain areas and in vast forests even those features and places that were of little importance but could serve as a help in finding one's position were to be provided with a name (IN1887, p. 173). The document from the year 1875 recommended to provide names of "single homesteads and houses that are located on exposed hills, visible from a distance, and enable finding one's position" as well as of "those that are of tactical importance and next to which it is possible to place artillery positions" (IN1875, p. 93).

Despite the previously mentioned importance of labels, already at the stage of the survey much attention was paid to avoiding an "overload", so that the final map did not include too many labels. Survey manuals tasked the surveyors with the duty of preliminary generalization of geographical names. The manual from the year 1875 stated:

„In case of higher label density the labels of minor importance that may be omitted on the

\footnotetext{
${ }^{5}$ All quotations from the Austro-Hungarian manuals translated are given in the author's own translation.
}

Spezialkarte are to be noted on label sheets in square brackets" (IN1875, p. 85).

The newest manual among the Austro-Hungarian ones even called label on a map (due to the fact that they hide its topographical content) "an unpleasant necessity" (IN1903, p. 167) and demanded:

"The necessary reduction of the number of toponyms becomes even more important in the case of the special map at the scale of $1: 75,000$, which is drawn on the basis of the survey sheets at the scale of $1: 25,000$. Since it is possible to assess the value of a name only on the spot, the rule is to be observed: only those geographical names are to be noted down on the survey sheets that shall be later on placed on the special map" (IN1903, p. 176).

However, the Polish manual of 1925 ordered in general that the names of minor importance that shall be omitted on maps at smaller scales are to be written on a label sheet in square brackets (IN1925, p. 121).

\section{Label processing and lay out according to the Austro-Hungarian manuals}

A surveyor did not place the collected toponyms directly on a drawing of a survey map, but on a label sheet instead. A label sheet was a separate overlay sheet, on which labels were placed. In Austria-Hungary names, after a preliminary generalization (as mentioned above, the names chosen to be omitted were marked on a label sheet), were transferred from the label sheet on the survey map during the so-called winter work (office work) by a clerk of a survey group or by the surveyor himself. However, it was the surveyor that was responsible for the correctness of the names transferred on the survey map sheet. It was his duty to inspect the work of the clerk and to check if the names on the survey map sheet are identical with the ones on the label sheet (IN1875, p. 87).

The Austrian regulations concerning the way the names from a label sheet were to be placed on a survey map sheet were included in the article 47 of IN1875, which shall be discussed here in a more precise way due to the essential importance of the manual for the 3rd survey. 
Labels could have been placed on a whole survey map sheet or on a part of it, before or after the hachure representation of relief had been drawn (IN1875, p. 87) (fig. 3). The main requirements a correct set of labels had to meet were: complete correctness of geographical names and their spelling, use of the pre- or - if this requirement could not be met - after the 60th kilometre of their length. Generally, names of areal features, buildings, and single features were to be placed parallel to the bottom frame of the survey map sheet; names of oblong features (oblong cultures, valleys, ravines, flowing waters, etc.) - along those features. In

\section{Daz Befchreiben fam auf Der ganzen Section 583.} poer auf ifhren einzelnen Theilen, vor ober nady dem

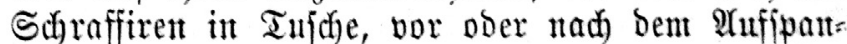
nent gejdefen; bort, wo in Folge bunfler Töne ber S(f)raffiruty viele Mamen ausgejpert werben müffen, ift bas Bef(yreiben beffer vor bent Sdyraffiren vor: zunehmen.

Fig. 3. A part of page 87 of IN1875

scribed typeface and size of letters, correct location of individual names and their proper layout. The labels had to be always placed in a way that allowed them to be easily read without turning the map. Moreover, they were required to hide as little topographic content of the map as possible and never hide any important elements of it. If the above mentioned requirements were possible to fulfil, the labels were to be placed the following way: names of towns, villages and of parts of them - east of the inhabited places, in the middle of its meridional extent; names of commune territories, names of cultures, and names of standing waters - inside the area if there was enough place available, otherwise obliquely over the surface or - as it was the case with single homesteads, minor features and other objects helpful in finding one's location - east of the places; names of mountain ridges - along the ridge; names of slopes - over their surface; names of peaks, summits and other minor parts of mountains - east of the feature with the initial letter directly next to it or over the feature (IN1875, p. 88). Names of flowing waters were placed inside their banks or - when there was not enough place available - outside the banks on one or the other side, along the downstream; names of railway lines and special names of roads - along those features. Rivers were labelled as such (sing. Fluss) only from the place where they become navigable case of lacking space a label may have been moved away from the feature (as little as possible) and connected with it with a small arrow. All railway lines and roads (and in areas with a weak road/railway system other main routes as well) were to be labelled close to the sheet frame with a label „von..." (from) and „nach..." (to), after which the name of the closest major locality was to be provided (IN1875, p. 89). The main general rule was to use "von" by the west frame and by the west halves of the north and south frame of a sheet and to use "nach" by the other parts of the sheet frame. If a road crossed the frame several times, only the outermost crossings were labelled (IN1875, p. 90).

If there was more than one name for a town, village, peak, forest, etc. the most commonly used name was to be written with the typeface prescribed for the given type of feature and the second (and if necessary the third name) was to be written with the same typeface but half the size and in brackets. The same applied to the names of suburbs, though in this case the brackets were not used. Had a mountain two different names used in two adjacent valleys - both were placed on the respective sides of the peak. Name division had to be avoided. It was acceptable only if no misunderstandings were possible. Letter-spacing was to be used when it was required by the range of a name, nevertheless the condition was that the legibility of such a label would not be hindered by other 
labels and the spaces between individual letters would not be too extensive so that it was clear that they constitute one entity. If these requirements could not be fulfilled - a multiplication of the label (without letter-spacing) within the range of the name was preferable (IN1875, p. 91). It shall be stressed here that the attention paid to the legibility of labels placed on a survey map with letter-spacing was highly advisable. Later on, labels placed with letterspacing on the Spezialkarte may have caused problems not only for common users of the $1: 75,000$ map, but even for cartographers using it as the basis for their further own cartographic works as well. The Polish Mapa turystyczna Karpat Polskich (The Tourist Map of the Polish Carpathians) at the scale of $1: 100,000$ that had been published sheet by sheet since 1928 by the Towarzystwo Kartograficzno-Wydawnicze GEA in Warsaw may serve here as a good example. The sheet Zone $13 \mathrm{Col}$ XXXI of the Austrian Spezialkarte from the year 1876 shows the Chornohora Mountains in the present Ukraine (the mountain range belonged to Poland before WWII). On the south slopes of a ridge located to the north of the village of Dzembronia (Дземброня) the sheet includes a letter-spaced name „Stepański”. In a distance of more or less three characters from the end of this label another letter-spaced label begins: "Jasienowir". However, on the sheet no. 3 of the Mapa turystyczna Karpat Polskich (which was based on the above mentioned sheet of Spezialkarte) there is the label „Stepański Jas” placed instead of „Stepański”. The discussed multi-sheet map published by the company GEA did not go down in the history of Polish tourism, but in its toponymic content it provides several more bizarre examples of a carefree name prosessing done by a GEA cartographer.

According to the manual of 1875 on the survey maps of the 3rd survey, names of states and administrative units were not placed within their borders. However, names of communes were fixed on the map. If a town or village was divided and shown on two sheets, the prescribed typeface and size of the label was used on the sheet that showed the bigger part of the locality. The part of the locality shown on the other sheet was labelled with the word "zu" (belonging to) and this label was made with the same typeface but half the size. This rule applied to the names of standing waters as well (IN1875, p. 92).

A survey map sheet had to show names of all inhabited places including hamlets. Locally well-known names of groups of houses were to be placed on a map as well. Moreover, labels had to be made for major factories, plants and manor houses. For the minor ones the labels had to placed only if they did not "overload" the map. The objects to be labelled this way had to be chosen according to their military importance (IN1875, p. 93). The names of trigonometric points were written with the typeface and in the size prescribed for the features that constituted these points (IN1875, p. 94).

In the names of mounts the element -berg (mountain) - if it belonged directly to a name (e.g. Kahlenberg, Schneeberg) - was written in its full form. Otherwise the word "Berg" was to be abbreviated to "B.". In case the common noun "Berg" did not appear in an oronym (mountain name), the abbreviation "B." was to be added only if it was possible to confuse the mountain with another not distant feature of a different type that had the same name (IN1875, p. 94).

All spot elevations symbols were labelled with labels written in black ink. In case of very dense hachures or a rocky terrain separate place was to be reserved for the label, which had to be placed parallel to the south frame of a sheet, generally east of the symbol (IN1875, p. 94). The rule of place reservation applied only to labels by spot elevations, but attention shall be drawn here to the general negative impact of the hachure representation of relief on the legibility of labels. This influence becomes especially arduous when one tries to excerpt toponyms from the Spezialkarte as well as from the survey maps of the 3 rd survey. The difficulty is even worse in case of the topographic materials of the 2 nd survey. Thus, every linguist using hachure maps as a source shall appreciate Prof. Eugeniusz Romer's efforts put into the popularization of contour lines as the method of relief representation.

The manual of 1887 elaborated the regulations concerning the placement of names on label sheets and the way their range was to be marked. The range of letter-spaced labels and the first or last letter or the centre of other labels were marked on a label sheet with a vertical stroke (fig. 4). The typeface and the size 
of label was indicated by a surveyor by noting the proper number from the legend (IN1887, p. 254). The principle of using specific colours for names of features of specific types was introduced. The colour prescribed for hydronyms was blue, for locality names - red, other labels were to be made in black (IN1887, p. 255). It shall be stressed here that this colour-code applied only to the labels on a label sheet. All the labels were later transferred on the survey map sheet by a clerk of a survey group only in black. The colour rules introduced in the 1887 manual became a long-lasting heritage of MGI present in the subsequent manuals issued by were done, 1883 the prescribed label sizes were changed, 1887 the decision was made to unify labels of survey map sheets and of the Spezialkarte (IN1887, pp. 355-356). If an older survey map served as an auxiliary material for a new survey drawing - the currently prescribed typefaces were to be used. On the other hand, in the case of a map revision in the field - the updates to the labels were to be done according to the rules binding at the time when the original survey had been conducted. In order to ease the use of proper regulations the surveyors were provided with tables of previously used typefaces (IN1887, p. 356).

\section{Biertel=Sdjrift=Srenten (auf Strohpapier).}

287. Dieje Dreatent müfjent bie in bie Section aujzunehmenden ßunn

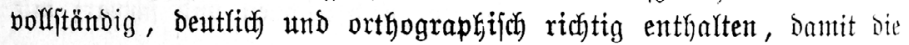
Bejureibung der Sectiong=Biertel bereitg während ber Zelbarbeit anftandsloz bewirft und nadträgliche correcturen, bie einen beseutellden Beitaufwand bedingen, vermiteden werben.

Auf ben Biertel=Sdhrift=Dleaten hat Der Mappeur, zut Serme

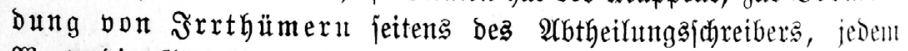
Worte bie Battung utto Srößze Der Safrift, mit Der fortfanfendell

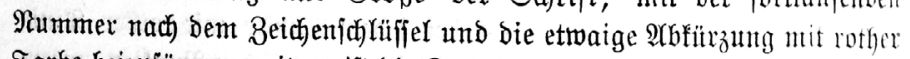
Farbe beizufügen; weiters ift bie \&age ber gejpertent, fowie ber itbrigen Schrift genau burch einten Strich für Den $\mathfrak{A}$ nffangas= ober (E)

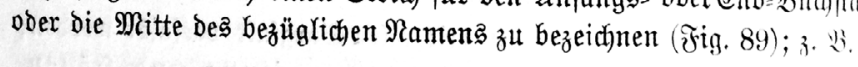

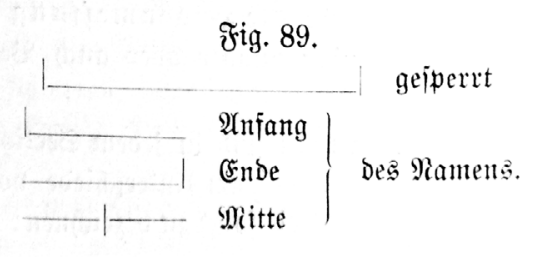

Fig. 4. A part of page 254 of IN1887. Marking of label placement on a label sheet

WIG: they were repeated in the WIG manual form the year 1925 (colour-code and the way of marking the range of a name) (IN1925, p. 119) and in the one from the year 1936 (colourcode only) (IN1936, p. 64).

When using a previously made survey maps an Austro-Hungarian surveyor had to pay attention to different versions of typeface and label size regulations that had been introduced since the time when the used survey map had been done: 1875 modifications of typefaces
The annex dating from the year 1894 included further regulations concerning labels. It stated that objects important for the military had to be labelled with a label so that they were better visible on the background of the topographic content. If it was useful for finding one's location, labels providing information on the feature were to be accompanied by the object's proper name. Collecting these names by a surveyor was of the greatest importance in the case of solitary castles, manor farms, mills, 
chapels, ruins, inns, forester's lodges, etc. If the objects had any special names or were called in a specific way by the locals, these expressions in a local language may have been added to the symbol or to the abbreviations next to it (AN1894, p. 16). Common nouns Strom, Fluss, Bach (two expressions for river, stream) or their equivalents in local languages were to be written only if these expressions were used in speech and writing next to the main proper name (AN1894, pp. 17-18). It shall be noticed that the later manuals (in contrast with IN1875) allowed for the use of common nouns (used together with or being an integral part of a geographical name) in the local national languages, which was of course intended to improve the communicative value of names on the map.

The annex from 1894 provides the following definition of a culture:

"Names of cultures. All areas used for the purposes of agricultural and forest production like gardens, fields, meadows, woods, pastures, etc. - given that they have their own stable names well-known in the nearest vicinity - are classified for the purpose of the military survey as cultures and labelled with proper labels. These names, also referred to as field names ${ }^{6}$, are in the case of maps and plans only of local value and can serve as an assistance in finding one's position only in smaller areas" (AN1894, pp. 18-19).

In the case of names of cultures the size of letters depended not only on the length, but on the width of the area as well (AN1894, p. 19).

In the case of localities with a scattered arrangement the label was to be placed with the proper typeface by their main part, by a temple or with letter-spacing in two or more places, so that it was clearly visible that a locality constitutes one entity (AN1894, p. 19). Names of parts of a locality that were separated from its main part by major features, e.g. by ridges or extensive forests, were written with a typeface prescribed for a given locality, but of a smaller size, and accompanied by the word "zu" (belonging to) (AN1894, pp. 19-20).

Italics were used for names of communes if they were not identical with any of the names of localities belonging to the commune. The official names of communes were accompanied

\footnotetext{
${ }^{6}$ Here in the original manual the terms Flurnamen and Riednamen are used.
}

by the word Gemeinde (commune) or the abbreviation "Gmd.". The names of communes accompanied by "zu..." were used for forests belonging to a given commune and for enclaves surrounded by other communes' territories (AN1894, p. 20).

An important rule was to write locality names and other proper names always in the full form (AN1894, p. 20), i.e. without any abbreviations, which were later on common on the WIG maps in the case of such adjectives as wielki, mały, dolny, górny (literally: great, small, lower, upper).

Names of higher units of orographic division were to be omitted on the survey map sheets. The examples of such names provided in the manual (AN1894, p. 25) are: Ostalpen, Österreichische Kalk-Alpen, Tauern, Karpatisches Waldgebirge. On the other hand, the names of smaller units of orographic division were to be placed on the sheets. The examples given in AN1894 are: Kleine Karpaten, Mátra, Fogarascher Gebirge, Cserhát, Jablunkaer Gebirge.

Due to the fact that mountain areas, ranges and groups as well as ridges often bear names typical for cultures (e.g. Wiener-Wald, BöhmerWald, Wald $=$ wood), the manual ordered to treat such toponyms as oronyms, notwithstanding the literal meaning of common nouns included in such names (AN1894, p. 25).

The discussed annex contained also some further remarks concerning the label legibility and the above mentioned great "graphical weight" of a hachure map. The labels had to be easy to read even in places with dark hachures and in areas with complex culture arrangement. It was to be achieved through a skilled placing of the labels in relation to the cultures as well as through drawing no hachures over letters and numbers, which, however, should have not led to the presence of any glaring "empty" places. Even though the legend prescribed specific letter sizes, the manual stated that "there is no doubt that in rare cases the abandonment of the prescribed label sizes for the sake of legibility seems to be not only justified, but even advisable" (AN1894, pp. 25-26).

The transfer of labels from label sheets on the survey map sheets began already during the field work. It was done with drawing ink (Zeichentusche). Later on, during the winter (office) work the labels were fixed with calligraphy ink (Stangenschreibtusche), which after drying 
was intensively black and matt and made the labels clear and legible on the survey sheets as well as on photographic reproductions. (AN1894, p. 26)

\section{Labels on the materials of the Third Survey and their layout on the Spezialkarte}

The impact of the regulations concerning the Third Military Survey of Austria-Hungary on the subsequent placing and form of labels on the Spezialkarte may be analysed on the basis of the materials available on the site Historical Maps of the Habsburg Empire (http://mapire.eu). The site contains the survey maps of the First and Second Military Survey of the Empire (including the 1st survey of Galicia), the hand-drawn maps of the Third Survey at the original scale of $1: 25,000$ of the Kingdom of Hungary ${ }^{7}$ and (labelled as the Third Survey) the 1:75,000 map (i.e. the Spezialkarte, which was actually based on the Third Survey). The site provides a synchronized view of two types of maps, which greatly facilitates the comparison of the materials of the 3rd survey $(1: 25,000)$ with the Spezialkarte. However, the site allows neither for the display of separate single survey map sheets nor for the display of single sheets of the Spezialkarte. Nevertheless, the edges of the merged sheets are visible. The comparison covers the survey map sheet Zone $13 \mathrm{Col}$ XXXI NW presented at mapire.eu, which probably served as the basis for the NW quarter of the Spezialkarte sheet Zone $13 \mathrm{Col}$ XXXI (issued 1876). The two corresponding parts of the sheets show the NW half of the Chornohora range with the Ukraine's highest summit of Hoverla.

According to the discussed manuals the numeric labels accompanying the spot eleva-

\footnotetext{
${ }^{7}$ It is to be supposed that the materials on the site are not labelled in a fully precise way. On the one hand the label "The Third Military Survey (1869-1887)" is given to what is in fact the Spezialkarte (the map being a generalization of the survey from $1: 25,000$ to $1: 75,000$ ), on the other the materials labelled as "Hungarian Kingdom (1869-1887) $(1: 25,000)$ " correspond to the regulations concerning the drawing and labels of the 3rd survey maps. It is not possible to state unambiguously if the maps shown at http://mapire.eu as the 3rd survey of the Hungarian Kingdom really served as the basis for the NW quarter of the sheet Zone $13 \mathrm{Col}$. XXXI of the Spezialkarte of 1876.
}

tions symbols were to be placed generally east of them. The comparative analysis of the survey material from mapire.eu and the sheet of the Spezialkarte leads to the following findings: in comparison with the survey map on the Spezialkarte: 65 spot elevation symbols (together with the accompanying labels) were omitted, 19 labels placed east of the sign and 2 placed west of the sign were left in the same position. In 10 cases labels were moved from the east (survey) to the west (Spezialkarte) position (e.g. the height of Hoverla and Pietros; in the latter case the hachures on the east slope of the mountain are much darker and the label on the survey map is hard to read). In 4 cases labels were moved from the west to the east position, and in two cases labels were moved in another way. Generally, as it was the case with other labels, the "shift" of labels accompanying spot elevation symbols took place due to the necessity of avoiding a collision with a neighbouring labels or avoiding the situation when a label would hide an element of the topographic content of the map.

As far as the generalization of toponyms is concerned, it has the greatest extent in the case of the names of flowing waters. Among such names of rivers and streams present on the survey map as many as 44 were omitted on the Spezialkarte, 6 were left in their original position, but their spelling was modified (e.g. Laźescina pt. $\rightarrow$ P. Laszczyna, Kozmiesczek pt. $\rightarrow$ P. Kożmieszczek), and in 6 cases both the spelling and the position were changed (in most cases the name was moved on the other bank). If the name of a river contained a common noun, the structure of the position whole name was usually changed from "Name + potok" na „P. + Name" (potok being a common noun for stream). Hydronyms containing the element zwur were in the most cases omitted in the generalization. However, in the case of isolated occurrences of this element on the Spezialkarte it was modified to the spelling zwór.

Generalization, however, did not apply to the names of peaks. On the survey maps there are only 4 labels of this type placed east of the peak whereas there are as many as 12 placed in a different way (generally above or beneath the summit). In the case of the Spezialkarte this numbers are respectively 2 and 13 (there is only one more summit name on the survey map). On the other hand numerous names of 
ridges containing the topographic common noun gruń that were present on the survey map were later on omitted on the Spezialkarte. In several cases when such ridge names were placed on the Spezialkarte the noun grun was, however, replaced with its "Polish" variant gron. An orthographic curiosity worth mentioning, present both on the survey map as well as on the Spezialkarte, is the old Polish spelling of the elongated vowel e (written with é, pronounced rather as [IPA symbols:] I than $\varepsilon$ ), which is to be found in the corresponding labels Széroki gruń and Széroki groń. South-west of the peak of Hoverla the label Breskul was modified from a (correct) form typical for ridge names to a form prescribed for names of peaks, even though the Spezialkarte does not show here any peak.

Many names of cultures were left, generally with no changes to their range, though sometimes with minor modification of their direction. Close to the north frame of the sheets the range of the name Stajki was modified through replacing the label with letter-spacing with a standard one. Moreover, in the names of cultures the common noun polonena was replaced with its Polish variant połonina.

On the Spezialkarte the labels "von" and "nach" were omitted in the places where a road crosses the sheet line. The omission is to be observed in the case of the labels added to standard map symbols as well, which, however, applies almost only to the word Stina or to its abbreviation St. ('shepherd's shelter').

The general finding is that the placing and the layout of labels on the survey map had an impact on the way they were placed on the final published topographic map. The generalization of the map's topographic content was accompanied by the generalization of the toponymic content (especially in the case of the names of flowing waters) and some minor shifts of the labels were done which, however, was caused mainly by a different size of labels and by the need to avoid the situation when letters would hide the topographic content.

\section{Label processing and lay out according to the Polish manuals}

The analysis of the manuals allows for some remarks concerning the influence the Austro-
Hungarian cartography had on the interwarPolish one.

As mentioned above, in Austria-Hungary after the preliminary generalization the names were copied from a label sheet directly on a hand-drawn survey map sheet. However, the practice in the Polish WIG was different and the labels were not transferred on a survey sheet. They remained only on a separate label sheet instead. An interesting amendment to this rule was proposed by lieutenant Wiktor Romanow from WIG:

"First of all, apart from the time scheduled for the field work (original survey, revision) some time should be devoted only to the preparation of a working name map. (...) The duties of a person processing the names (geographer) should include: 1) placing names on a working map showing the terrain and the roads together with an appropriate classification of names (names of mountains, rivers, pastures, etc.), 2) exact, if possible cartographic, marking of the name ranges, 3) classification of names according to the size of the named features. A map prepared this way would serve as a typical working map (...)

Name sheets prepared by the survey officers for every map sheet during a revision or a topographic survey do have some properties of such a working map. A surveyor marks on a label sheet the limits of a name's range, though it applies only to the names of localities; the administrative affiliation of scattered localities is marked this way. The limits of the range of other names (of marshes, mountains, meadows, fields, woods, etc.) are not given this way, which makes the work of cartography officers much more difficult. The lack of topographic objects and relief on a label sheet results in the fact that names are sometimes placed on a final map not exactly in the same place where they were placed by a surveyor on a label sheet and this may again result in an incorrect range of a given name on the map (...)

(...) This way of placing new names or correcting old ones directly on maps was successfully used by the pre-war Austrian survey service, (the 1:75,000 maps)" (W. Romanow 1929, pp. 137-138).

It may be supposed that in the last paragraph W. Romanow refers indeed to the Austro-Hungarian practice of transferring selected labels from a label sheet directly on a survey map, 
which took place in the final stage of the survey map preparation immediately before it was handed over to a cartographer. Nevertheless, as it is to be found in IN1936, Romanow's suggestions were not accepted, i.e. the "working name map" was not introduced. On the other hand, the IN1936 manual prescribes that the range of names of woods, mountains, meadows, etc. be marked on a label sheet.

The 1925 rules of marking the placing of labels and indicating the letter size corresponded to the ones from the Austrian manual of 1887 (IN1887, p. 254; IN1925, p. 119); the issue of the colour-code used on the label sheets has been already mentioned above. If a part of a locality was separated from its main part, the name had to be - as it was the case with the Austrian regulations - accompanied by the preposition “do" (to) (IN1925, p. 119; AN1894, pp. 19-20).

The Polish manual from the year 1925 coincides with the Austro-Hungarian regulations also when it comes to the labels for suburbs (half the size, no brackets), administrative units (omission applied to names of states, provinces, counties, and - in contrast to the Austro-Hungarian manuals - communes), rivers, streams and orographic units ("general names of mountains" - e.g. Carpathians - were omitted, but names of smaller regions were placed on maps) (IN1925, p. 120). Slightly different was, however, the rule concerning placing the names of peaks - as the standard solution the Polish manual prescribed an arch-like layout. (IN1925, p. 120).

As mentioned above, the Polish manual of 1936 did not recognize the suggestions made by Lt Romanow - labels were not transferred to the survey map and remained only on separate label sheets. A surveyor had to place names collected in the field on a "working label sheet", which could consist of several separate sheets. During the quarter work a surveyor prepared a "fair copy" - a sheet made on linen (IN1936, pp. 62-63).

The main content of a label sheet consisted of the names of settlements, i.e. separate groups of houses that had their own names. A name had to be given for every settlement, accompanied by a number of houses a settlement consisted of. If a given name referred at the same time to a village, a manor, a manor farm, etc., the abbreviations $D$. (manor), $F w$. (manor farm), G. (forester's lodge) added to the map symbols were not accompanied by this name. Had the mentioned objects their own names different from the name of a village, these names were added to the abbreviations (IN1936, p. 62).

The Polish manuals prescribed placing on survey maps rather numerous labels presenting information on the administrative organization and property issues concerning forests. Apart from a name of a wood the name of a forest area (in a full or abbreviated form, e.g. Nadleśnictwo or Ndl. Dąbrowa) or information on the manor estate the wood belonged to, e.g. Las maj. Jabłonów) was placed on a survey map (IN1936, pp. 62-63).

It is visible at first glance that the above discussed regulations concerning survey map labels applied to the final printed WIG map as well. A fair copy of a label sheet had to contain all labels that were to be placed on a map. Moreover, a surveyor had to note as many names as possible. The size of an object decided on the size of letters. Label colours prescribed for specific types of objects and name ranges coincided with the regulations present in the Austro-Hungarian manuals and in the Polish manual of 1925 . Any labels providing additional information that were not present in the standard set of abbreviations were to be written in a full form (IN1936, pp. 63-64).

Symbols of trigonometric, levelling, and spot elevation points were placed on a survey map with black ink and accompanied on their right side by a label showing the elevation. In the case of objects protected by law (natural monuments or monuments of architecture) an appropriate symbol on a survey map was accompanied by a standard abbreviation Ochr. (protection) (IN1936, p. 64).

Red continuous line was used to mark the range of a locality name, which was placed in the middle of the area marked this way and accompanied by a number of houses in the locality (written beneath the locality name). Black ink was used to mark the range of names of woods, mountains, meadows, etc. The names were written without a common noun such as "łąka" (meadow), "góra" (mount), "las" (wood) unless these common nouns were used as an integral part of a name. A label sheet contained numbers of forest division quarters. Blue line was used for flowing waters and for borders of 
standing waters. Those blue lines were broken in places where names were placed. (IN1936, pp. 64-65).

A label sheet was supplemented by a "name list”, which contained the following columns:

1) Item no., 2) Feature type (e.g. village, hamlet, manor farm, forester's lodge, lake, etc.), 3) Name, 4) Source of the name (e.g.: Commune authorities, locals., teacher, etc.), 5) Number of houses, 6) Number of inhabitants, 7) Genitive form / applies only to names with dubious pronunciation or spelling, 8) Adjective form / applies only to names with dubious pronunciation or spelling, 9) Remarks. The last column provided space for explanations concerning e.g. dubious names (IN1936, p. 65; annexes to IN1936: Wzór Nr. 2 Wykaz nazw).

The regulations of the WIG manual concerning map revision (IN1937) coincided in general with IN1936, though some differences are to be found: in the case of updating maps produced by WIG a label sheet contained only these labels that differed from the labels on the updated map. An area containing new labels was marked on a label sheet with a double black line. In the case of updating maps that had been not produced by WIG (i.e. AustroHungarian, German and Russian maps) a new complete label sheet was to be prepared for the whole updated sheet (IN1937, p. 40).

\section{Sources of toponymic material}

Both Austro-Hungarian and Polish manuals defined the sources of names a surveyor had to consult before the launch of the filed work. This issue is, however, closely connected with the linguistic form of toponyms placed as labels on maps, and therefore it is discussed in a much more precise way in a separate paper (W. Włoskowicz, Toponomastyczna praca topografa...). The older Polish manual mentioned e.g. "excerpts form statistical books" (IN1925, p. 118) whereas the newer mentioned e.g. "official registers of settlement names" (IN1936, p. 5). In practice a WIG surveyor may have used mainly a publication by the Polish Central Statistical Office Skorowidz miejscowości Rzeczypospolitej Polskiej opracowany na podstawie wyników Pierwszego Powszechnego Spisu Ludności z dn. 30 września 1921 r. i innych źródeł urzędowych (a settlement name register based on the first census of Poland). The preparation of this work was a task assigned to the Census Department of the Central Statistical Office. The way the book was prepared is discussed by Rajmund Buławski (1930). He points out that "the Central Statistical Office, considering itself not competent in the toponomastic matters, made no efforts to make the register of settlement names presented in the Skorowidz miejscowości... an officially binding document" (R. Buławski 1930, p. 137). In Austria-Hungary the surveyors had similar documents prepared by the state statistical institutions at their disposal.

\section{Conclusions}

The differences between the Austrian and Polish regulations are worth pointing out once again. The transfer of labels from label sheets on the survey map sheets at the very last stage of work exempted a cartographer from deciding on the range and placing of names. Of course, as discussed above, some minor label shifts were done, e.g. due to the fact that a label of the same size and typeface "hid" on the 1:75,000 map a much bigger area than on the original $1: 25,000$ survey map. Shifts made for the sake of better legibility of labels were caused to a certain extent by the very characteristics of the monochromatic printed map. On the other hand, the WIG surveyors did not transfer the labels on the survey map sheets and the toponyms remained only on the separate label sheets, which is why in the case of WIG the influence of a cartographer on the location of names on a map was somehow greater. 


\section{Sources and literature}

AN1894 - Anhang A zur Instruction für die militärische Landesaufnahme. II. Technischer Theil. Wien 1894. The manual is available at Fachbereichsbibliothek Geographie und Regionalforschung of the University of Vienna, in one volume with IN1887.

Buławski R., 1930, Metoda opracowania wykazu osiedli zawartego w „Skorowidzu miejscowości Rzeczypospolitej Polskiej”. „Wiadomości Służby Geograficznej” T. 4, z. 2, pp. 124-140.

Czarnota T., 1930, Polski Przegląd Kartograficzny tom I-Il. „Wiadomości Służby Geograficznej” T. 4, z. 1, pp. 99-107.

Faluszczak F., 2011, Kartografia Galicji Wschodniej. Rzeszów: Wydawn. Uniwersytetu Rzeszowskiego.

IN1875 - Instruction für die militärische Landesaufnahme (Militärmappirung). II. Theil. Wien 1875. The manual is available at Universitätsbibliothek Wien, Hauptbibliothek, I 193 680; in one volume with part one and three of the manual.

IN1887 - Instruction für die militärische Landesaufnahme (Militär-Mappirung und Reambulierung). II. Technischer Theil. Wien 1887. The manual is available at Fachbereichsbibliothek Geographie und Regionalforschung of the University of Vienna.

IN1903 - Instruction für die militärische Landesaufnahme. II. Technischer Theil. [The 2nd ed.]. Wien 1903.

IN1925 - Instrukcja topograficzna. Część II techniczna. Warszawa 1925.

IN1936 - Instrukcja topograficzna Wojskowego Instytutu Geograficznego. Część III. Zdjęcie stolikowe. Warszawa 1936.

IN1937 - Instrukcja topograficzna Wojskowego Instytutu Geograficznego. Część IV. Unacześnianie map. Warszawa 1937.

Konias A., 2000, Kartografia topograficzna Śląska Cieszyńskiego i zaboru austriackiego od II połowy XVIII wieku do początku XX wieku. Katowice: Wydawn. Uniwersytetu Śląskiego.

Romanow W., 1929, Organizacja prac nad ustaleniem nazw miejscowości w Polsce. „Wiadomości Służby Geograficznej” T. 3, z. 3-4, pp. 130-139.

Włoskowicz W., Toponomastyczna praca topografa w Austro-Wegrzech i w II Rzeczypospolitej (the article has been accepted for publication in the journal „Prace Językoznawcze”, http://uwm.edu.pl/ polonistyka/pracejezykoznawcze/). 